\title{
Membangun Motivasi Belajar Peserta Didik SD pada Masa Pandemi Menggunakan Reward
}

\section{Wahyu Irmawati}

SD Negeri Dukuhseti 04

wahyuirmawati27@gmail.com

\section{Article History}

received 3/12/2020

\begin{abstract}
Learning during the Covid-19 pandemic demands to create innovation and creativity in supporting the online learning process. The reality is that a lot of learning received by students is monotonous only in the form of assignments without any feedback or reinforcement of student learning outcomes. This causes students to become bored, lack enthusiasm in learning, and many students prefer to play rather than study during a pandemic because there is no motivation or reinforcement from the teacher. Giving rewards is very important given by teachers to students as feedback, reinforcement and appreciation because students have been willing to learn every day. Teachers should strive to provide rewards in innovative forms so that students feel interested and happy in learning. Rewards can be in the form of words of praise, giving a score of 100, a thumb sticker, a smile or other sign of encouragement that the teacher can give to students to raise enthusiasm for learning.
\end{abstract}

Keywords: motivation, the covid-19 pandemic, reward

\begin{abstract}
Abstrak
Pembelajaran pada masa pandemi Covid-19 menuntut untuk menciptakan inovasi dan kreatifitas dalam menunjang proses pembelajaran daring. Kenyataan yang terjadi, banyak pembelajaran yang diterima peserta didik secara monoton hanya berupa penugasan tanpa adanya umpan balik ataupun penguatan terhadap hasil belajar peserta didik. Hal ini mengakibatkan peserta didik menjadi bosan, tidak ada semangat dalam belajar, dan banyak peserta didik yang lebih menyukai bermain daripada belajar di masa pandemi karena tidak ada motivasi atau penguatan dari guru. Pemberian reward penting sekali diberikan oleh guru kepada peserta didik sebagai umpan balik, penguatan dan apresasi karena siswa telah mau belajar setiap harinya. Guru hendaknya berupaya dalam memberikan reward dalam bentuk yang inovatif agar siswa merasa tertarik dan senang dalam belajar. Pemberian reward dapat berupa kata-kata pujian, pemberian skor 100, tanda sticker jempol, tanda senyum atau tanda penyemangat lainnya yang dapat diberikan guru kepada peserta didik guna membangkitkan semangat dalam belajar.
\end{abstract}

Kata kunci: motivasi belajar, masa pandemi, reward

Social, Humanities, and Education Studies (SHEs): Conference Series https://jurnal.uns.ac.id/shes

p-ISSN 2620-9284 e-ISSN 2620-9292 


\section{PENDAHULUAN}

Dunia pendidikan erat kaitannya dengan belajar dan pembelajaran. Seorang guru harus berusaha memfasilitasi peserta didik agar dalam mengembangkan potensi dalam dirinya ketika belajar. Dalam proses pembelajaran terdapat tiga aspek yang perlu dikembangkan guru kepada peserta didik yaitu aspek sikap, pengetahuan dan ketrampilan. Selain sebagai fasilitator, guru juga berperan sebagi motivator yaitu memberikan dan mendorong motivasi, semangat, serta kegairahan peserta didik sehingga tercipta keaktifan peserta didik dalam belajar. Menurut Gage dalam Puji Sumarsono (2020), "Belajar sebagai suatu proses sehingga suatu organisme berubah perilakunya sebagai akibat pengalaman. Apabila terjadi perubahan perilaku pada suatu organisme yang diakibatkan oleh kematangan, bukan merupakan belajar. Perubahan dalam sifat-sifat fisik, misalnya berat dan tinggi badan bukan termasuk belajar." Berdasarkan pendapat tersebut, proses perubahan perilaku peserta didik dalam belajar sebagai akibat dari pengalaman. Dengan demikian, guru harus menciptakan suasana belajar yang menyenangkan dan dapat memotivasi peserta didik agar tercipta pengalaman belajar yang baik.

Motivasi mempunyai peranan penting dalam proses belajar mengajar baik bagi guru maupun peserta didik. Bagi guru mengetahui motivasi belajar dari peserta didik sangat diperlukan guna memelihara dan meningkatkan semangat belajar peserta didik. Bagi peserta didik motivasi belajar dapat dapat menumbuhkan semangat belajar sehingga peserta didik terdorong untuk melakukan perbuatan belajar. Peserta didik melakukan aktivitas belajar dengan senang karena didorong motivasi (Endang Titik Lestari, 2020). Dengan demikian, motivasi memang sangat diperlukan dalam suatu proses pembelajaran karena dengan adanya motivasi dari guru akan timbul semangat belajar peserta didik.

Pada masa pandemi Covid-19, pembelajaran dilakukan secara daring. Guru dituntut untuk menciptakan inovasi dan kreatifitas dalam menunjang proses pembelajaran daring. Kenyataan yang terjadi, banyak pembelajaran yang diterima peserta didik secara monoton hanya berupa penugasan tanpa adanya umpan balik ataupun penguatan terhadap hasil belajar peserta didik. Hal ini mengakibatkan peserta didik menjadi bosan, tidak ada semangat dalam belajar, dan banyak peserta didik yang lebih menyukai bermain daripada belajar di masa pandemi karena tidak ada motivasi atau penguatan dari guru. Padahal pembelajaran daring seharusnya tidak menjadi kendala bagi guru dalam memberikan motivasi agar peserta didik semangat dalam belajar.

Berdasarkan permasalahan di atas, ada beberapa upaya yang bisa dilakukan guru untuk memberikan motivasi kepada peserta didik di masa pandemi. Salah satunya yaitu memberikan penguatan berupa reward melalui aplikasi Whats App atau Google Classroom. Reward yang diberikan harus dapat memberikan manfaat yang baik bagi peserta didik. Reward yang diberikan bisa berupa kata-kata pujian, pemberian skor 100, tanda sticker jempol, tanda senyum atau tanda penyemangat lainnya yang dapat dikirimkan guru kepada peserta didik melalui aplikasi Whats App atau Google Classroom yang diberikan setiap kali peserta didik selesai mengirimkan tugas. Pemberian reward ini penting sekali diberikan oleh guru kepada peserta didik sebagai umpan balik, penguatan dan apresasi karena siswa telah mau belajar setiap harinya.

Reward merupakan bagian dari penguatan yang diberikan guru sebagai usaha peningkatan motivasi belajar. Dengan semakin seringnya guru memberikan reward kepada peserta didik akan semakin menambah semangat peserta didik dalam belajar karena reward sebagai bentuk perhatian guru kepada peserta didik. Bagi peserta didik yang sering tidak mengerjakan tugaspun harus diberikan motivasi secara terus menerus agar tumbuh semangat dalam belajar dan ketika peserta didik sudah mulai rajin belajar diberikan penguatan berupa reward sehingga peserta didik merasa 
senang dan akan lebih semangat lagi dalam belajar. Pemberian penguatan melalui reward juga dapat mempermudah guru untuk mengetahui kesulitan yang dialami peserta didik dalam mengikuti pembelajaran daring.

\section{A. Motivasi Belajar}

\section{HASIL DAN PEMBAHASAN}

Huitt,W dalam Siti Suprihatin (2015) mengatakan motivasi adalah suatu kondisi atau status internal (kadang-kadang diartikan sebagai kebutuhan, keinginan, atau hasrat) yang mengarahkan perilaku seseorang untuk aktif bertindak dalam rangka mencapai suatu tujuan. Dengan demikian, motivasi merupakan suatu kebutuhan yang mengarahkan seseorang untuk aktif dalam mencapai suatu tujuan. Motivasi belajar sebenarnya merupakan dorongan atau stimulus yang dirasakan oleh peserta didik ketika melakukan pembelajaran di kelas (Felia Febrianti, 2019). Membangun motivasi belajar pada peserta didik khususnya anak usia Sekolah Dasar memang tidaklah mudah mengingat karakteristik peserta didik SD masih senang bermain. Dalam pandangan Ngalim Purwanto, motivasi memiliki tiga fungsi pokok. Pertama, mendorong manusia untuk berbuat atau bertindak. Motivasi tersebut berfungsi sebagai penggerak atau motor yang memberikan energi (kekuatan) kepada seseorang untuk melakukan tugas. Kedua, menentukan arah perbuatan, yakni ke arah suatu tujuan atau cita-cita. Motivasi mencegah penyelewengan dan jalan yang harus ditempuh untuk mencapai tujuan itu. Ketiga, menyeleksi perbuatan. Artinya menentukan perbuatanperbuatan mana yang harus dilakukan, guna mencapai tujuan tertentu dengan mengenyampingkan perbuatan yang tidak bermanfaat bagi tujuan yang dimaksud. (Karwadi dalam Felia Febrianti, 2019). Berdasakan hal tersebut, motivasi memiliki fungsi yang positif demi kemajuan dan semangat belajar peserta didik.

Motivasi belajar peseta didik tidak lepas dari pehatian guru. Seorang anak akan lebih semangat belajar jika merasa diperhatikan oleh pendidik atau yang berada di sekitarnya.Oleh karena itu, peran serta guru harus dioptimalkan dalam pembelajaran. Dengan pemberian motivasi yang optimal akan membangun semangat peserta didik untuk belajar tanpa diminta dan ditunggui. Hal ini akan memberikan dampak yang baik bagi tumbuh kembang peserta didik, kondisi emosial dan peningkatan hasil belajar peserta didik. Pemberian motivasi belajar secara optimal kepada peserta didik juga akan menjadikan peserta didik menjadi lebih mandiri atau tidak bergantung kepada orang lain ketika belajar dan memecahkan persoalan. Peserta didik juga akan memiliki kepercaan diri yang baik serta mampu berinteraksi secara baik dengan temannya ataupun lingkungannya. Motivasi memiliki peranan strategis dalam kegiatan belajar seseorang, karena apabila tidak ada motivasi maka kegiatan belajar tidak ada. Oleh karena itu, sebagai seorang motivator, guru harus melakukan berbagai cara (termasuk pemberian reward) agar dapat mendorong para siswanya untuk tekun belajar dan giat belajar.

Motivasi diperlukan dalam menentukan intensitas usaha belajar bagi para peserta didik. Menurut Djamarah dalam Siti Suprihatin (2015) ada tiga fungsi motivasi, yakni :

a) Motivasi sebagai pendorong perbuatan. Motivasi berfungsi sebagai pendorong untuk mempengaruhi sikap apa yang seharusnya anak didik ambil dalam rangka belajar.

b) Motivasi sebagai penggerak perbuatan. Dorongan psikologis melahirkan sikap terhadap anak didik itu merupakan suatu kekuatan yang tak terbendung,yang kemudian terjelma dalam bentuk gerakan psikofisik.

c) Motivasi sebagai pengarah perbuatan. Anak didik yang mempunyai motivasi dapat menyeleksi mana perbuatan yang harus dilakukan dan perbuatan yang perlu diabaikan. 
Dengan demikian, motivasi memiliki beberapa fungsi yang sangat berpengaruh dalam pembelajaran, Motivasi sebagai pendorong perbuatan, penggerak perbuatan, dan pengarah perbuatan peserta didik sehingga menjadi kebiasaan yang lebih baik.

\section{B. Sistem Pembelajaran Pada Masa Pandemi}

Pandemi Covid-19 yang terjadi di berbagai negara khususnya di Indonesia membuat aktivitas atau kegiatan manusia sedikit terkendala tak terkecuali dalam pendidikan. Pemerintah membuat kebijakan sosial distancing. Menurut Luh Devi Herliandry (2020), kebijakan social distancing maupun physical distancing guna meminimalisir penyebaran Covid-19 mendorong semua elemen pendidikan untuk mengaktifkan kelas meskipun sekolah tutup. Penutupan sekolah menjadi langkah mitigasi paling efektif untuk meminimalisir penyebaran wabah pada anak-anak. Solusi yang diberikan yakni dengan memberlakukan pembelajaran di rumah dengan memanfaatkan berbagai fasilitas penunjang yang mendukung. Selama masa pandemi Covid-19 pembelajaran dirumah atau online menjadi solusi melanjutkan sisa semester. Dengan demikian, pemerintah sudah berupaya dalam menekan angka penyebaran Covid-19 dengan kebijakan sosial distancing dan memberlakukan pemberlakuan peserta didik untuk belajar di rumah melalui pembelajaran online.

Pembelajaran online didefinisikan sebagai pengalaman transfer pengetahuan menggunakan video, audio, gambar, komunikasi teks, perangkat lunak (Basilaia \& Kvavadze, 2020) dan dengan dukungan jaringan internet (Zhu \& Liu, 2020). Oleh karena itu, guru dituntut untuk berinovasi dan berkreativitas dalam merancang metode dan media pembelajaran yang menarik sehingga dapat menunjang pembelajaran daring. Pembelajaran daring atau pembelajaran online memang banyak terjadi kendala terlebih lagi di beberapa daerah yang mengalami kesulitan jaringan. Tetapi kendala tersebut tidaklah menjadi sesuatu yang berarti bagi guru dalam mengembangkan kreatifitasnya. Ada banyak solusi yang bisa dilakukan untuk mengatasi permasalahanpermasalahan atau kendala yang terjadi selama pembelajaran daring pada masa pandemi. Pemanfaatan media pembelajaran yang inovatif menggunakan zoom, google meet atau sejenisnya dapat memfasilitasi dalam interaksi tatap maya antara guru dan siswa pada masa pandemi.

\section{Reward}

Reward sering diartikan sebagai hadiah. Menurut Yopi Nisa Febianti, reward adalah ganjaran, penghargaan, imbalan, atau hadiah. Penghargaan atau hadiah yang diberikan karena sesuatu telah dilakukan dengan baik dan benar. Reward adalah akibat yang diberikan sebagai imbalan karena kita sudah melakukan sesuatu yang baik, benar, dan memuaskan. Menurut Sardiman (2014, hlm.46), "Reward merupakan salah satu bentuk motivasi belajar yang diberikan guru". Lalu Syah (2013, hlm.153) mengatakan bahwa, "Hadiah merupakan contoh nyata motivasi ekstrinsik yang menolong siswa belajar". Sedangkan Suryabrata (2013, hlm.237) mengemukakan bahwa, "Adanya ganjaran sebagai salah satu faktor psikologi belajar saat akhir belajar". Berdasarkan pendapat dari beberapa ahli tersebut, reward dapat didefinisikan sebagai perlakuan yang menyenangkan sebagai salah satu faktor psikologi belajar, juga merupakan bentuk contoh nyata motivasi ekstrinsik yang diberikan guru untuk menolong peserta didik belajar karena berhasil meraih prestasi memuaskan. Pemberian reward akan membuat peserta didik bersemangat dalam belajar dan akan membentuk sebuah kebiasaan yang positif yaitu akan belajar tanpa diperintah.

Penguatan (reinforcement) diberikan pendidik (guru) kepada peserta didik (siswa) dengan maksud untuk membesarkan hati peserta didik, agar mereka lebih aktif berpartisipasi dalam interaksi belajar-mengajar, juga mengontrol perubahan tingkah laku siswa ke arah negatif. Dengan penguatan (reinforcement), peserta didik dapat 
lebih fokus belajar, memiliki motivasi untuk belajar, dan aktif selama pembelajaran, juga tingkah laku mereka dapat dibina untuk lebih produktif ke arah yang positif. Jenisjenis penguatan (reinforcement) menurut Usman (2013, hlm.81-82) adalah sebagai berikut:

1. Penguatan verbal Biasa diungkapkan atau diutarakan dengan kata-kata pujian, penghargaan (valuation), persetujuan, dan sebagainya, misalnya bagus; bagus sekali; betul; pintar; ya; seratus buat kamu!

2. Penguatan non verbal, yaitu:

a. Penguatan gerakan isyarat, misalnya mengangguk atau menggelengkan kepala, tersenyum, mengerutkan kening, mengancungkan jempol, raut muka sedih, raut muka ceria, serta sorot mata yang memandang bersahabat (tajam).

b. Penguatan pendekatan: Guru melakukan pendekatan pada siswa untuk memberikan perhatian dan kesukaannya terhadap mata pelajaran, perilaku, atau penampilan rapi siswa. Misalnya, guru berdiri disamping siswa, berjalan menuju siswa, duduk dekat seorang siswa atau sekelompok siswa, atau berjalan di sisi siswa. Penguatan ini bermanfaat untuk menambah penguatan verbal.

c. Penguatan sentuhan (contact): Guru memberikan persetujuan atau memberikan penghargaan bagi siswa atas usaha dan penampilan mereka dengan cara menepuk bahu atau pundak siswa, menjabat tangan siswa, mengangkat tangan siswa atas kemenangan dalam pertandingan. Penguatan sentuhan harus digunakan dengan seksama agar sesuai dengan usia siswa, jenis kelamin siswa, dan latar belakang kebudayaan setempat.

d. Penguatan dengan aktivitas menyenangkan: Guru memakai aktivitas atau tugas yang disukai oleh siswa sebagai penguatan. Misalnya, seorang siswa menunjukkan kemajuan pada mata pelajaran seni musik ditunjuk menjadi ketua paduan suara di sekolahnya.

e. Penguatan berupa benda/simbol: Guru memakai penguatan ini dengan berbagai

simbol berupa benda, misalnya kartu bergambar, bintang plastik, lencana, ataupun komentar tertulis di buku siswa. Hal tersebut jangan terlalu sering dilakukan untuk menghindari kebiasaan dalam mengharapkan sesuatu sebagai imbalan.

f. Jika siswa memberikan jawaban kurang tepat, guru seharusnya tidak langsung menyalahkan siswa. Apabila terjadi seperti itu, alangkah lebih baik guru memakai penguatan tak penuh (partial). Contoh, apabila siswa hanya bisa menjawab sebagian yang benar, alangkah lebih baik guru menyatakan, "Oke, jawaban Anda benar, tetapi harus disempurnakan", maka siswa tersebut akan mengetahui bahwa jawaban yang diberikan tidak seluruhnya salah, dan siswa tersebut terdorong untuk menyempurnakan jawabannya lagi.

Penguatan verbal maupun penguatan non verbal sangat penting dilakukan untuk mendorong keaktifan, semangat, dan motivasi belajar peserta didik saat melakukan kegiatan belajar di kelas. Meskipun pada kenyataannya, guru lebih baik menggunakan kedua jenis penguatan tersebut secara bersama-sama saat memberikan reward kepada siswa dalam kegiatan belajar-mengajar agar lebih meyakinkan. Saat reward diberikan melalui sebuah penguatan verbal dan penguatan non verbal, peserta didik secara pasti akan mengetahuinya, bahwa ia atau mereka telah diberikan reward oleh guru mereka. Selama kegiatan belajar-mengajar berlangsung, pendidik selalu memberikan reward kepada peserta didiknya melalui penguatan yang didasari atas rasa kasih sayang dan tanggung jawab. Kasih sayang yang diberikan pendidik kepada peserta didiknya mampu membuat mereka melakukan tanggung jawab mereka dalam memberikan pembelajaran dengan baik. (Yopi Nisa Febianti, 2018). Penguatan verbal 
dan non verbal dapat diterapkan dalam pembelajaran serta penggunaan reward agar menjadikan peserta didik semangat dalam belajar.

\section{Pemberian Motivasi Berupa Reward Pada Pembelajaran Daring}

Pada masa pandemi, pemberian motivasi agar siswa giat belajar dan semangat belajar salah satu caranya adalah dengan pemberian reward secara virtual. Guru harus menciptakan inovasi dalam pemberian reward agar bervariasi. Pemberian reward dapat berupa kata-kata pujian, pemberian skor 100, tanda sticker jempol, tanda senyum atau tanda penyemangat lainnya yang dapat diberikan guru kepada peserta didik guna membangkitkan semangat dalam belajar. Hal ini dapat dilakukan ketika siswa telah menyelesaikan tugas pada pembelajaran daring dapat disampaikan nilai siswa tersebut disertai kata-kata penyemangat. Pemberian reward harus rutin diberikan guru agar peserta didik merasa termotivasi dalam belajar tanpa paksaan. Selain itu juga dapat menjalin kedekatan antara guru dan peserta didik sehingga guru dapat mengetahui kesulitan yang dialami peserta didik selama pembelajaran. Reward juga sebagai penguatan. Penguatan (reinforcement) merupakan semua bentuk respons, bersifat verbal/non verbal, bagian modifikasi perilaku guru terhadap perilaku siswa, dengan pemberian informasi atau umpan balik (feedback) sebagai tujuan bagi si penerima (siswa) atas perbuatannya, sebagai dorongan ataupun koreksi. Atau penguatan (reinforcement) adalah respons terhadap perilaku yang dapat meningkatkan kemungkinan berulangnya kembali perilaku tersebut.

Pemberian reward virtual yang berbentuk animasi dapat diberikan kepada siswa melalui Whats App grup agar orang tua siswa juga mengetahui dan memudahkan guru untuk menyampaikan informasi kepada siswa ketika pembelajaran daring. Pembuatan reward animasi harus semenarik mungkin agar siswa tertarik dan senang dalam belajar sehingga meningkatkan semangat belajar siswa. Selain mampu meningkatkan semangat belajar anak, Astari et al., (2020) menyimpulkan bahwa pemberian reward mampu mempengaruhi sosial emosional anak. Dimana reward digunakan oleh guru untuk memberikan penghargaan atas diri anak seutuhnya. Guru memberikan reward kepada anak supaya anak lebih giat dalam mengikuti pembelajaran. Hal tersebut didukung dengan hasil penelitian Puspitasari (2015), yang menyatakan bahwa reward dapat mempengaruhi kemampuan belajar anak. Namun guru dan orangtua harus memperhatikan, agar pemberian reward ini tidak berdampak buruk pada perkembangan potensi anak. Dengan demikian, pemberian reward sangatlah penting dan guru harus berupaya dalam memberikan reward dalam bentuk yang inovatif agar siswa merasa tertarik dan senang dalam belajar.

\section{SIMPULAN}

Pembelajaran daring memberikan kemudahan dalam memberikan transfer informasi pada berbagai situasi dan kondisi. Ragam manfaat dari kemudahan pembelajaran online didukung berbagai platform mulai dari diskusi hingga tatap muka secara virtual. Namun, hal ini perlu di evaluasi dan disesuaikan dengan kondisi setempat, mengingat kemampuan orang tua memberikan fasilitas pembelajaran daring berbeda. Langkah memaksimalkan kemampuan peserta didik belajar dalam kondisi pandemi seperti ini salah satu caranya adalah dengan pemberian reward kepada peserta didik untuk meningkatkan movitasi dan semangat belajar peserta didik. Pemberian reward secara online bisa melalui Whats App grup agar orang tua juga mengetahui pencapaian belajar dan kesulitan yang dialami peserta didik. Guru harus menciptakan inovasi dalam pemberian reward agar bervariasi. Pemberian reward dapat berupa kata-kata pujian, pemberian skor 100, tanda sticker jempol, tanda senyum atau tanda penyemangat lainnya yang dapat diberikan guru kepada peserta didik guna membangkitkan semangat dalam belajar. 


\section{DAFTAR PUSTAKA}

A.M., Sardiman. (2014). Interaksi \& Motivasi Belajar Mengajar. Jakarta: Rajawali Pers. Lestari, Endang Titik. 2020. Cara Praktis Meningkatkan Motivasi Siswa Sekolah Dasar. Yogyakarta: CV Budi Utama.

Febianti, Yopi Nisa. (2018). Peningkatan Motivasi Belajar Dengan Pemberian Reward And Punishment Yang Positif, 6 (2), 93-102.

Febrianti, Felia. (2019). Efektivitas Penggunaan Media Grafis Dalam Meningkatkan Motivasi Belajar Siswa, 2 (1), 667-677.

Herliandry, Luh Devi. (2020). Pembelajaran Pada Masa Pandemi Covid-19, 22 (1), 6570.

Astari, T., Nur Aisyah, S., \& Andika Sari, D. (2020). Tanggapan Guru Paud Tentang Pemberian Reward Dan Pengaruhnya Terhadap Motivasi Belajar Dan Perkembangan Sosial Emosional Anak Usia Dini. JECIES: Journal of Early Childhood Islamic Education Study, 1(2), 141-155.

Puspitasari, R. (2015). Pengaruh Pemberian Hadiah (Reward) Terhadap Kemandirian Belajar Anak Di Tk Tunas Muda Karas. Prosiding Ilmu Pendidikan, 1(2), 53-55.

Sumarsono, Puji dkk. (2020). Belajar dan Pembelajaran di Era Milenial. Malang: UMM Press.

Suprihatin, Siti. (2015). Upaya Guru Dalam Meningkatkan Motivasi Belajar Siswa, 3 (1), 73-82.

Usman, U. (2013). Menjadi Guru Profesional. Bandung: PT Remaja Rosdakarya.

Zhu, X., \& Liu, J. (2020). Education in and After Covid-19: Immediate Responses and LongTerm Visions. 